\title{
Analysis of the Student's Initial Needs on Development Instructional Videos Dribble Directly Jumpshoot Exercise Model
}

\author{
Rian Handika \\ Postgraduate Program, \\ Universitas Negeri Medan, \\ Medan, Indonesia \\ Email:ryanhandikalubis11@gmail.com
}

\author{
Tarsyad Nugraha \\ Postgraduate Program, \\ Universitas Negeri Medan, \\ Medan, Indonesia
}

\author{
Sabaruddin Yunis Bangun \\ Postgraduate Program, \\ Universitas Negeri Medan, \\ Medan, Indonesia
}

\begin{abstract}
Basketball is one of the most popular sports in the world. This study aims to determine the student's initial needs towards the development of instructional videos on the dribble directly jumpshoot exercise model. The research method used is observation and interview. The results obtained from this study are the dribble directly jumpshoot movement some students still do not have a good balance that causes the body to shake easily in the air and the accuracy of the shot is reduced besides that there are still some students who dribble the wrong way because bouncing the ball is too strong and can't control the direction of the ball. Students who have a jumpshoot dribble ability are not good at $70.75 \%$, students who feel the need to practice their dribble and jumpshoot skills are $89.35 \%$, students who consider dribble directly jumpshoot training are still monotonous at $\mathbf{9 8 . 7 \%}$, students who find it difficult to increase their dribble directly jumpshoot skills by $\mathbf{9 3 . 1 3 \%}$, and students who agree to the development of instructional video dribble directly jumpshoot exercise model at $\mathbf{1 0 0 \%}$. The conclusionof this study is that there needs to be a development in dribble directly jumpshoot training conducted by students so that their dribble directly jumpshoot skills can be better.
\end{abstract}

Keywords - dribble, jumpshoot, basketball

\section{INTRODUCTION}

There are many ways to be healthy. One of them by exercising regularly because with regular exercise besides healthy can also enjoy life. Among the teenagers who are the problem is the difficulty of choosing the type of sport that suits the teenagers today. Most of them like sports that look trend among them. Like for example, sports basketball [1].

Bolabasket is one of the most popular sports in the world [2]. The number of competitions that show that basketball is a sport of achievement. Extracurricular becomes a place for students to practice, develop talent, and achieve an achievement in playing basketball. Surely a good training program is required in an extracurricular basketball to achieve an achievement [3].

Based on interviews with trainers who do research on extracurricular activities in Vocational High School 1 (SMK N 1), Senior High School (SMA) Kesuma Indah, and Senior
High School 3 (SMA N 3) Padangsidimpuan obtained the result that students who choose to follow extracurricular basketball is the highest number of other sports that is equal to $37.5 \%$ of 4 sports branch in SMK N 1 Padangsidimpuan; $40.68 \%$ of the 3 sports in SMA Kesuma Indah Padangsidimpuan; and $41.93 \%$ of the 3 sports in SMA N 3 Padangsidimpuan. It shows that sports basketball is very popular.

The purpose of the exercise is to achieve a desired achievement, of course the basketball athlete must master the basic techniques of basketball games with both individually. The basic techniques in basketball are passing, dribbling, shooting, pivot and rebound [2]. In basketball, dribbles are a fundamental advantage: no player with a ball can move for the field if he does not dribble [4]. In addition to the ability of dribble in basketball shooting ability is also very important. Shooting is an important factor in determining the outcome and to win the game. There are different types of shooting techniques in basketball that are jump shoots, free throws, hook shoots and lay up shoots. Jump shoots are the most powerful technique to get the points that get the most attention from coaches and players [5].

The problem of trainers in dribbling and Jump shoot is usually hampered by several factors, for example, lack of skilled trainers in demonstrating dribbling and jump shoot movements or coach age factors that are not possible to demonstrate themselves. For the current learning media is very important to be given because it can help a smooth and successful training process. With the media students are also better able to understand the movements to be performed other than an example of a teacher or trainer. Media created must be really interesting and easy to understand by students. The solution or media that is the creation of the media in the form of instructional video dribble exercise model directly jump shoot on the sport of basketball.

This research is a preliminary research conducted to determine the ability of dribble and jump shoot owned by students and the initial needs of students on the development of instructional video dribble exercise model jump shoot directly. So researchers can know the shortcomings of the 
existing training process and can add more variety of interesting exercises to put in instructional videos to be developed.

\section{METHODS}

The research was conducted by observing the students who participated in the extracurricular activities of basketball at SMK N 1, SMA N 3, and SMA Kesuma Indah Padangsidimpuan. The implementation was done in May 2018.

The population in this study is all participants of extracurricular basketball in every school where the research. The samples were chosen by using total sampling technique, meaning the whole of the population is the whole students who participated in basketball extracurricular activities at SMK N 1, SMA N 3, and SMA Kesuma Indah Padangsidimpuan.

This research is a non experimental design, meaning that no treatment is given to the research subject which enables special impact on measurable variables.

The test of dribble and jump shoot capability is done by looking at how many dribbles and jump shoot can be done within 1 minute with the right movement. To find out the initial needs of students on the development of instructional videos dribble exercise model jump shoot directly done by giving a questionnaire containing 5 questions to be answered by students with a choice of answers "YES" or "NO". Then the results obtained are calculated the percentage by using the formula:

$$
\text { Percentage }(\%)=\frac{\text { number of answers }}{\text { number of respondents }} \times 100 \%
$$

\section{RESUlT AND DiSCUSSION}

The results of the observations of the researchers on the ability of dribble and jump shoot students is still there are some movements that are less than the maximum, for example when doing a jump shoot motion some players still do not have a good balance that causes the body easily shake while in the air and the accuracy of the shots to be reduced. In addition there are still some students who do dribble in the wrong way as the reflection of the ball is too strong and can not control the direction of the ball. This shows that in reality the trainers have not been able to apply their knowledge to the students who will be trained, in addition to the training model provided by the trainer is still monotonous and the lack of progress of the training given so that students feel bored in following extracurricular basketball then the trainer needs to get basketball coaching.

In the training process, actively guiding students to learn basketball should take precedence, so the future development of students through basketball has great help. At this stage, the teaching of basketball in the application of basketball games is increasingly in the method, in order to improve the level of students' ability in basketball [6]. Then the training process can not be underestimated, because only with a lot of practice students can achieve his achievements, especially in sports basketball.

The results of the initial needs analysis of students can be seen in Table 1, Table 2, and Table 3.

TABLE 1. PERCENTAGE OF INITIAL STUDENT NEEDS ANALYSIS RESULTS IN SMA KESUMA INDAH PADANG SIDIMPUAN

\begin{tabular}{|c|c|c|c|c|}
\hline \multirow{2}{*}{ Question } & \multicolumn{2}{|c|}{ Answer a } & \multicolumn{2}{c|}{ Answer b } \\
\cline { 2 - 5 } & total & \% & total & \% \\
\hline 1 & 30 & $62.5 \%$ & 18 & $37.5 \%$ \\
\hline 2 & 43 & $89.58 \%$ & 5 & $10.42 \%$ \\
\hline 3 & 48 & $100 \%$ & - & - \\
\hline 4 & 45 & $93.75 \%$ & 3 & $6.25 \%$ \\
\hline 5 & 48 & $100 \%$ & - & - \\
\hline
\end{tabular}

TABLE 2. PERCENTAGE OF INITIAL STUDENT NEEDS ANALYSIS RESULTS IN SMA N 3 PADANGSIDIMPUAN

\begin{tabular}{|c|c|c|c|c|}
\hline \multirow{2}{*}{ Question } & \multicolumn{2}{|c|}{ Answer a } & \multicolumn{2}{c|}{ Answer b } \\
\cline { 2 - 5 } & total & $\mathbf{\%}$ & total & \% \\
\hline 1 & 19 & $73.07 \%$ & 7 & $26.93 \%$ \\
\hline 2 & 23 & $88.46 \%$ & 3 & $11.54 \%$ \\
\hline 3 & 25 & $96.1 \%$ & 1 & $3.9 \%$ \\
\hline 4 & 24 & $92.31 \%$ & 2 & $7.69 \%$ \\
\hline 5 & 26 & $100 \%$ & - & - \\
\hline
\end{tabular}

TABLE 3. PERCENTAGE OF INITIAL STUDENT NEEDS ANALYSIS RESULTS IN SMK N 1 PADANGSIDIMPUAN

\begin{tabular}{|c|c|c|c|c|}
\hline \multirow{2}{*}{ Question } & \multicolumn{2}{|c|}{ Answer a } & \multicolumn{2}{c|}{ Answer b } \\
\cline { 2 - 5 } & total & $\mathbf{\%}$ & total & $\mathbf{\%}$ \\
\hline 1 & 23 & $76.67 \%$ & 7 & $23.33 \%$ \\
\hline 2 & 27 & $90 \%$ & 3 & $10 \%$ \\
\hline 3 & 30 & $100 \%$ & - & - \\
\hline 4 & 28 & $93.33 \%$ & 2 & $6.67 \%$ \\
\hline 5 & 30 & $100 \%$ & - & - \\
\hline
\end{tabular}

If averaged percentage for the three schools then the result is that students who have the ability dibble and jump shoot less good $70.75 \%$, students who feel the need to practice dribble skills and jump shootnya of $89.35 \%$, students who consider dribble exercise and jumpshoot performed at this time is monotonous equal to $98.7 \%$, student who find it difficult to increase dribble ability and jumpshootnya equal to $93.13 \%$, and student who agree if done dribble training development jump shoot jump $100 \%$. So it can be concluded that the need for development in the dribble and jump shoot exercises conducted by students to dribble ability and jump shoot them better.

In the previous training process a media provided by a coach is limited to the exemplary movement, images alone or even not given. For that there is need for development in the current training process. Media is very important to be given because it can help a smooth and successful training process. With the media students are also more able to understand the movement to be done. Media created must be really interesting and easy to understand by students. Making instructional video media dribble exercise model jump shoot directly on basketball is expected to help students to learn the movement. The video media created there must be the steps of the movements performed. The video was made in a simple but interesting way for students to learn. The advantages of this video for example, can be played repeatedly at home, movement or form of exercise is always the same because the form of video. 


\section{CONCLUSION}

Based on the results of the study it can be concluded that the dribble directly jumpshoot ability students is still low and it is necessary to develop the exercises that have been done.

\section{REFERENCES}

[1] F. Y. Budianti, S. Supriyadi, and O. Andiana, "Pengembangan Latihan Pass-Shoot Bola Basket Melalui Media Audio Visual Pada Club Bola Basket Gosweet Gondanglegi Malang”, Jurnal Sport Science, 6(2), 2017.

[2] A. B. Darmawan, O. B. Januarto, and U. Wahyudi, "Pengembangan Model Latihan Kombinasi Dribbling, Passing dan Shooting Peserta Ekstrakurikuler Bolabasket di SMP Negeri 2 Kota Malang", Jurnal Pendidikan Jasmani, 26(2), 2016.
[3] A. Aziz, "Faktor Fisik dan Teknik Pada Kemampuan Dribble Atlet Ekstrakurikuler Bola Basket Putra Tingkat SMA", Pend. Kepelatihan Olahraga-S1, 1(6), 2016.

[4] G. Altavilla, A. P. Di Tore, T. D’Isanto, and G. Raiola, "Some Teaching Method Elements of the Basketball Dribble", Journal of Sports Science, 5, 207-210, 2017.

[5] M. A. Khazaeli, H. Sadeghi, A. Rahimi, M. Mirmoezzi, "Comparison Of Selected Kinematic Parameters Of The Ball Movement At Free Throw And Jump Shot Of Basketball Adult Players", Indian Journal of Fundamental and Applied Life Sciences, 5(S3), 2549-2553, 2015.

[6] F. Liu, "Study on Strategies of Basketball Game in Basketball Teaching", International Conference on Frontiers in Educational Technologies and Management Sciences (FETMS 2017), 2017. 